\title{
PEMBERIAN KOMPOS PADA TANAH BEKAS TAMBANG DENGAN INDIKATOR TANAMAN SAWI (Brassica chinensis $L$ )
}

\section{THE EFFECTS OF COMPOST APPLICATION ON EX-MINING LAND WITH CHINESE CABBAGE (Brassica chinensis $L$ ) AS INDICATOR}

\author{
Karamoy Lientje Theffie, Wiesje J.N. Kumolontang dan Jenny Rondonuwu*) \\ *Fakultas Pertanian Unsrat Manado
}

\begin{abstract}
This research aimed to determine the effects of compost applications on ex-mining lands by using chinese cabbage as indicator. The experiments were conducted at the Faculty of Agriculture greenhouse and the soil and compost analysis were done at the Soil Chemistry and Fertility Laboratory for a duration of two months. The research employed a Completely Randomized Design method with 5 treatments repeated 3 times to get 15 experimental units. The analysis on ex-mining soil revealed that it contained only trace amounts of soil nutrients $\mathrm{N}, \mathrm{P}$, and $\mathrm{K}$. The laboratory analysis on the compost sample resulted in a $\mathrm{C} / \mathrm{N}$ ratio of 11.87 which suggested that the compost was mature and ready to be used. The Analysis of Variance on research data showed that compost applications did not affect plant height between treatments at each weekly observation, and similarly did not affect leaf quantity and fresh weight at harvest time. However, the research found that the compost applications tended to improve plant height, leaf quantity, and fresh weight of plants at harvest time. The minimal effect of compost applications between treatments suggested that the plants did not utilized the nutrients supplied by the compost in their early stages of development. Moreover, it was also suspected that the compost applications had not been sufficient in supplying the soil nutrients needed by the plants to ensure proper growth which ultimately affected the fresh weight of the plants at harvest time.
\end{abstract}

Keywords: compost, ex-mining land

\begin{abstract}
ABSTRAK
Penelitian ini bertujuan menentukan pengaruh pemberian kompos pada tanah bekas tambang dengan indikator tanaman sawi. Penelitian ini dilakukan di Rumah Kaca Fakultas Pertanian dan analisis tanah serta kompos dilakukan di Laboratorium Kimia dan Kesuburan Tanah dengan lama penelitian 2 bulan. Penelitian dirancang menggunakan Rancangan Acak Lengkap (RAL) dengan 5 (lima) perlakuan serta diulang sebanyak 3 (tiga) kali sehingga diperoleh 15 satuan percobaan. Hasil penelitian kandungan hara $\mathrm{N}, \mathrm{P}$ dan $\mathrm{K}$ tanah bekas tambang tergolong sangat rendah. Hasil analisis kompos diperoleh ratio $\mathrm{C} / \mathrm{N} 11.87$ hail ini menunjukkan pupuk kompos yang digunakan telah matang dan siap digunakan. Hasil analisis sidik ragam menunjukkan pemberian pupuk kompos tidak berpengaruh antar perlakuan terhadap tinggi tanaman pada setiap minggu pengamatan, demikian juga jumlah daun dan berat segar tanaman saat panen. Tetapi dari hasil penelitian dapat dilihat ada kecenderungan terjadi peningkatan tinggi tanaman, jumlah daun dan berat segar tanaman saat panen dengan adanya pemberian kompos. Tidak adanya pengaruh pemberian kompos antar perlakuan pada penelitian ini menunjukkan tanaman pada awal pertumbuhan belum seluruhnya menggunakan hara yang ada pada kompos. Selain itu kemungkinan pemberian kompos belum mampu menyediakan hara yang dibutuhkan tanaman untuk pertumbuhannya yang berpengaruh pada produksi tanaman dalam hal ini berat segar tanaman saat panen.

Kata kunci: kompos, tanah tambang
\end{abstract}

Eugenia Volume 21 No. 2 Juni 2015 


\section{PENDAHULUAN}

Tanah bekas tambang merupakan tanah yang miskin unsur hara dan kurangnya mikroorganisme yang ada dalam tanah. Dengan kata lain tanah bekas tambang memiliki masalah baik dari sifat kimia, fisik dan biologi tanah. Keadaan sifat fisik, kimia dan biologi tanah yang kurang baik sangat menentukan kemampuan tanah untuk berproduksi dengan baik. Uasha pertanian dapat saja dilakukan pada tanah bekas tambang dengan memberikan bahan organik dalam jumlah yangh cukup untuk membantu proses fisik dan kimia serta biologi yang akan berlangsung pada tanah tersebut.

Pemberian bahan organik berupa kompos merupakan alternatif yang sangat baik dalam pengelolaan tanah bekas tambang. Kompos merupakan salah satu jenis pupuk organik. Kompos adalah bahan organik yang telah menjadi lapuk, seperti daun-daunan, jerami, alang-alang rumput-rumputan, serta kotoran hewan. Pemberian pupuk kompos berfungsi sebagai sumber unsur hara dalam tanah, memperbaiki kandungan bahan organik tanah, memperbaiki struktur tanah, dan mendorong kehidupan jasad renik tanah. Selain itu pupuk kompos dapat memperbaiki sifat-sifat fisik tanah seperti permeabilitas tanah, prositas tanah, daya menahan air tanah dan kation-kation tanah (Hardjowigeno, 2003).

Pemberian pupuk organik secara teratur pada tanah tropika yang digunakan untuk produksi sayuran, terutama pada budidaya sayuran intensif harus dilakukan, sebab bahan organik dapat memperbaiki struktur dari pada tanah. Struktur tanah yang baik memungkinkan pertukaran $\mathrm{CO}_{2}$ dan $\mathrm{O}_{2}$ yang mencukupi untuk keperluan aktivitas akar. Tanpa pemberian pupuk organik, tanah yang dikelola terus-menerus untuk penanaman sayuran akan menjadi padat, memungkinkan pori-pori tanah akan berkurang aerasi buruk, sehingga perakaran tidak berkembang dengan baik, pertumbuhan tanaman terhambat.

Tanaman sawi merupakan salah satu jenis sayuran yang banyak dibudidayakan karena tingginya permintaan masyarakat pada tanaman tersebut. Tanaman sawi menghendaki tanah yang gembur dan membutuhkaan hara yang cukup da- lam proses pertumbuhannya. Tanaman ini dapat tumbuh baik pada daerah dataran tinggi dan juga dataran rendah. Pertumbuhannya sangat tergantung pada ketersediaan hara yang ada dalam tanah serta lingkungan fisik tanah yang baik untuk pertumbuhannya.

Berdasarkan permasalahan yang ada pada tanah bekas tambang maka perlu adanya penambahan pupuk dalam hal ini kompos untuk pertumbuhan tanaman. Tetapi jumlah yang ideal perlu dilakukan penelitian agar produksi yang optimal dapat tercapai.

Penelitian ini bertujuan untuk menentukan pengaruh pemberian kompos pada tanah bekas tambang dengan indikator tanaman sawi.

\section{METODE PENELITIAN}

Penelitian ini dilaksanakan di rumah kaca Fakultas Pertanian Unsrat, dengan lama penelitian dua bulan. Analisa tanah dan kompos dilakukan di Laboratorium Kimia dan Kesuburan Tanah Fakultas Pertanian Unsrat Manado.

Bahan yang digunakan dalam penelitian ini adalah: tanah bekas tambang, pupuk kompos, benih sawi, air dan bahan kimia untuk analisis tanah. Alat yang digunakan dalam penelitian ini yaitu: dari ember, meteran, timbangan, dan alat tulis-menulis, karung, timbangan dan sekop serta alat laboratorium untuk analisis tanah.

Penelitian ini mengunakan rancangan acak lengkap (RAL) dengan perlakuan sebagai berikut:

$\mathrm{A}=0 \mathrm{ton} / \mathrm{Ha}$

$\mathrm{B}=10 \mathrm{ton} / \mathrm{Ha}$

$\mathrm{B}=20$ ton $/ \mathrm{Ha}$

$\mathrm{D}=30$ ton $/ \mathrm{Ha}$

$\mathrm{E}=40$ ton $/ \mathrm{Ha}$

Setiap perlakuan diulang sebanyak 3 (tiga) kali sehingga diperoleh 15 satuan percobaan.

\section{Prosedur Kerja \\ Di Laboratorium}

Tanah bekas tambang dikering-anginkan, kemudian diayak dan selanjutnya ditimbang. Analisis sifat kimia tanah meliputi: $\mathrm{pH}, \mathrm{N}$ total, $\mathrm{P}$ tersedia dan $\mathrm{K}$-tersedia serta $\mathrm{C}$ - organik tanah 


\section{Di Rumah Kaca}

Tanah bekas tambang ditimbang sebanyak $5 \mathrm{~kg}$ dan dicampur dengan kompos sesuai dengan dosis yang telah ditentukan kemudian disirami dengan air sampai jenuh, lalu dinkubasi selama 2 minggu. Setelah 2 minggu benih sawi ditanam. Setelah tanaman berumur seminggu dilakukan penjarangan dimana setiap ember dibiarkan 2 tanaman. Pemeliharaan tanaman dan pengendalian hama di lakukan apabila ada serangan. Pengamatan tinggi tanaman dan jumlah daun dilakukan setiap minggu. Panen dilakukan setelah tanaman berumur 6 minggu dan ditimbang berat segar tanaman.

\section{Variabel yang diamati}

Tinggi tanaman, jumlah daun dan berat segar sawi setelah dipanen.

\section{Analisa Data}

Data dianalisis dengan menggunakan sidik ragam dan apabila berpengaruh dilanjutkan $\mathrm{Uji}$ Beda Nyata Terkecil (BNT) $5 \%$.

\section{HASIL DAN PEMBAHASAN}

\section{Sifat Kimia Tanah Bekas Tambang dan Kompos} Hasil analisis kimia tanah dan kompos yang digunakan tertera pada Tabel 1.

Kandungan hara dari tanah yang digunakan dalam penelitian ini dikategorikan untuk nitrogen sangat rendah, fosfor sangat rendah, kalium sangat rendah dan C-organik tergolong sangat rendah. Berdasarkan hasil tersebut dapat dilihat bahwa tanah yang digunakan tingkat kesuburan tanahnya dikategorikan sangat rendah. Melihat masalah ini maka dalam pengelolaan tanah tersebut perlu dilakukan penambahan unsur hara dalam bentuk pupuk. Penambahan unsur hara dimaksudkan untuk meningkatkan ketersediaan unsur hara yang dibutuhkan oleh tanaman. Tanah dengan kandungan unsur hara yang sangat rendah tidak dapat mendukung pertumbuhan tanaman yang dibudidayakan.

Hasil analisis kompos menunjukkan ratio $\mathrm{C} / \mathrm{N}$ 11.87. Nilai ini menunjukkan bahwa pupuk organik tersebut telah matang dan siap untuk digunakan. Prinsip pengomposan pada dasarnya menurunkan ratio $\mathrm{C} / \mathrm{N}$ bahan organik sehingga mendekati ratio $\mathrm{C} / \mathrm{N}$ tanah. Jika ratio $\mathrm{C} / \mathrm{N}$ tinggi mengakibatkan immobilisasi $\mathrm{N}$ sehingga mikroorganisme dan tanaman memperebutkan unsur $\mathrm{N}$ tersedia pada tanah. Immobilisasi $\mathrm{N}$ adalah perubahan $\mathrm{N}$ anorganik menjadi $\mathrm{N}$-organik oleh mikroorganisme untuk menyusun jaringan-jaringan dalam tubuhnya (Hakim, et. al., 1986). Hal ini terjadi karena adanya persaingan dengan mikroorganisme tanah untuk memperebutkan unsur hara. Karbon dan Nitrogen sangat penting untuk memasok hara yang dibutuhkan mikroorganisme sebagai sumber energi dan Nitrogen untuk membentuk protein (Sutanto, 2002). Selain itu nitrogen sangat dibutuhkan tanaman dalam proses pertumbuhan awal tanaman.

\section{Tinggi Tanaman}

Hasil analisis sidik ragam menunjukkan tidak adanya perbedaan yang nyata antar perlakuan kompos terhadap tinggi tanaman pada beberapa waktu pengamatan.

Tabel 2 menunjukkan bahwa, tinggi tanaman meningkat seiring dengan bertambahnya dosis kompos yang diberikan walaupun tidak berbeda nyata di antara perlakuan lainnya. Hal ini menunjukkan bahwa pemberian kompos mampu meningkatkan pertambahan tinggi tanaman. Tidak adanya pengaruh yang nyata antar perlakuan kemungkinan disebabkan karena pemberian pupuk kompos belum seluruhnya unsur yang diberikan digunakan oleh tanaman tetapi kemungkinan terjadi persaingan dengan mikroorganisme.

Tabel 1. Sifat Kimia Tanah dan Kompos

(Table 1. Chemical Characteristics Of Soils and Compost)

\begin{tabular}{lllllll}
\hline Perlakuan & N Total & $\mathrm{P}_{2} \mathrm{O}_{5}(\mathrm{ppm})$ & $\mathrm{K}_{2} \mathrm{O}(\mathrm{ppm})$ & $\mathrm{C}$-org $(\%)$ & $\mathrm{pH}$ & $\mathrm{C} / \mathrm{N}$ \\
\hline Tanah & $0.02(\mathrm{SR})$ & $4.58(\mathrm{SR})$ & $2.30(\mathrm{SR})$ & $0.6(\mathrm{R})$ & 6.0 & \\
Kompos & 0.96 & 24.57 & 13.05 & 11.4 & 6.4 & 11.87 \\
\hline
\end{tabular}

Keterangan: $S R=$ sangat rendah, $R=$ Rendah 
Tabel 2. Pengaruh Pemberian Kompos terhadap Tinggi Tanaman

(Table 2. Effect of Adding Compost to Plant Height)

\begin{tabular}{ccccc}
\hline Perlakuan & 14HST & 21 HST & 28 HST & 35 HST \\
\hline A & 12.65 & 14.75 & 17.88 & 22.23 \\
B & 13.64 & 15.45 & 18.89 & 24.25 \\
C & 15.67 & 17.67 & 20.21 & 27.56 \\
D & 16.34 & 18.27 & 21.27 & 28.65 \\
E & 16.87 & 18.25 & 22.27 & 27.75 \\
\hline
\end{tabular}

Selain itu pemberian kompos belum mampu menyediakan hara yang dibutuhkan tanaman menyebabkan pembelahan sel akar terhambat sehingga pertumbuhan vegetatif terganggu. Kompos yang diberikan dalam tanah mengalami serangkaian reaksi dan berubah dari senyawa kompleks menjadi senyawa sederhana melalui proses enzimatik yang dilakukan oleh mikroorganisme (Buckman dan Brady, 1982).

Tanaman yang tidak diberi kompos menunjukkan nilai tinggi tanaman yang lebih rendah. Hal ini menunjukkan bahwa tanaman sangat membutuhkan unsur hara yang lebih dari yang ada dalam tanah. Tidak adanya penambahan unsur hara menyebabkan proses pembelahan sel dalam tanaman terganggu akibatnya pertumbuhan tanaman terhambat.

Hasil penelitian juga menunjukkan walaupun tidak ada pengaruh nyata antar perlakuan tetapi ada kecenderungan peningkatan tinggi tanaman seiring dengan peningkatan takaran atau dosis pupuk yang diberikan. Makin tinggi takaran pupuk kompos maka tinggi tanaman juga meningkat. Hal ini menunjukkan pasokan hara dari kompos sangat dibutuhkan tanaman. Jadi pupuk kompos mampu menghasilkan unsur hara yang dibutuhkan tanaman sehingga dapat diserap tanaman. Unsur tersebut digunakan dalam proses metabolisme yang menunjang proses pembelahan sel sehingga terjadi pertumbuhan tinggi tanaman.

\section{Jumlah Daun}

Berdasarkan hasil sidik ragam pengaruh pemberian kompos terhadap jumlah daun me- nunjukkan tidak adanya perbedaan yang nyata antar perlakuan. Rata-rata jumlah daun disajikan pada Tabel 3.

Tabel 3 menunjukkan bahwa jumlah daun tertinggi berada pada minggu terakhir pada perlakuan $D$ dengan dosis 30 ton/ha. Hal ini menunjukkan bahwa dosis 30 ton/ha mampu meningkatkan jumlah daun karena ketersediaan hara yang cukup untuk menunjang pertumbuhan tanaman. Tanaman yang diberi kompos dengan dosis yang lebih kecil menunjukkan bahwa jumlah daun memiliki nilai yang lebih rendah. Pemberian kompos memberikan respon terhadap jumlah daun. Apabila tanaman kurang mendapatkan unsur hara tambahan dalam bentuk pupuk, menyebabkan pembelahan sel akar terhambat sehingga pertumbuhan vegetatif terganggu yang berpengaruh pada produksi atau panen.

Pemberian pupuk organik dalam hal ini kompos akan mentransformasikan unsur $\mathrm{N}, \mathrm{P}$, dan $S$ dalam tanah sehingga pemupukan kompos dapat menyumbangkan $\mathrm{N}$ dalam tanah yang sangat dibutuhkan bagi pertumbuhan vegetatif termasuk jumlah daun. Pemberian kompos 30 ton/ha dapat memberi kontribusi hara yang cukup sehingga pertambahan jumlah daun meningkat. Adanya unsur $P$ yang cukup dalam tanah sangat membantu dalam proses metabolisme energi (Soepardi, 1980). Pemberian $\mathrm{P}$ mempengaruhi pertumbuhan akar yang akan menyerap unsur hara sehingga kebutuhan hara dalam proses pertumbuhan tanaman akan berjalan lancar. 
Tabel 3. Pengaruh Pemberian Kompos Terhadap Jumlah Daun

(Table 3. Effect of Adding Compost to Leaves Amount)

\begin{tabular}{ccccc}
\hline Perlakuan & 14HST & 21 HST & 28 HST & 35 HST \\
\hline A & 2 & 3 & 5 & 7 \\
B & 3 & 4 & 6 & 9 \\
C & 3 & 4 & 7 & 11 \\
D & 4 & 5 & 8 & 13 \\
E & 3 & 5 & 8 & 12 \\
\hline
\end{tabular}

\section{Berat Segar Sawi Saat Panen}

Tabel 4. Berat Basah Tanaman Untuk Masing-Masing Perlakuan

(Table 4. Wet Weight Plant for Each Treatment)

\begin{tabular}{cc}
\hline Perlakuan & Berat Basah Tanaman $(\mathrm{gr})$ \\
\hline A & 18.25 \\
B & 22.11 \\
C & 23.11 \\
D & 25.12 \\
E & 24.54 \\
\hline
\end{tabular}

Hasil sidik ragam, menunjukkan tidak ada pengaruh nyata takaran kompos terhadap berat segar tanaman sawi pada saat panen. Tetapi terjadi penambahan berat dengan adanya pemberian pupuk kompos. Tidak ada pengaruh nyata kemungkinan disebabkan oleh kandungan hara dalam tanah sangat rendah serta dosis pupuk kompos yang diberikan belum mampu untuk menyediakan hara yang cukup untuk produksi tanaman. Kecenderungan meningkatnya berat segar dengan pemberian kompos pada dosis 30 ton/ha.

Pada Tabel 4 terlihat bahwa pemberian kompos 30 ton/ha menunjukkan nilai yang tertinggi pada berat segar sawi. Keadaan ini memberi petunjuk bahwa pemberian kompos 30 ton/ha dapat menyumbangkan hara yang dibutuhkan tanaman. Pemberian pupuk organik memungkinkan tersedianya Nitrogen yang dibutuhkan tanaman. Nitrogen berfungsi sebagai pembentuk protein (Hardjowigeno, 2003). Protein digunakan dalam tanaman untuk pembelahan sel. Terjadinya pembelahan sel mengakibatkan terjadi pula penambahan berat tanaman dalam hal ini berat segar tanaman.

Tidak adanya perbedaan yang nyata antar perlakuan menunjukkan bahwa kompos jika diberikan pada awal penanaman belum seluruhnya dapat diserap oleh tanaman. Hasil penelitian ini menunjukkan bahwa pemberian kompos mampu memperbaiki sifat fisik, kimia dan biologi tanah yang mendorong pertumbuhan tanaman. Roesmarkum, $d k k$. (2002) mengemukakan bahwa pemberian pupuk organik yang belum masak pengaruhnya akan terlihat pada beberapa tahun ke depan. Harajati, $d k k$. (1996) dalam penelitiannya mengemukakan bahwa dampak positif dari penggunaan kompos dapat dilihat nyata pada tanaman yang berumur panjang.

\section{KESIMPULAN}

Pemberian kompos pada tanah bekas tambang tidak memberikan pengaruh nyata pada pertumbuhan tanaman sawi namun ada kecenderungan meningkat dengan adanya pemberian kompos dan tertinggi pada perlakuan 30 ton/ha.

\section{DAFTAR PUSTAKA}

Buckman dan Brady. 1982. IImu Tanah. Terjemahan Soegiman. Bhratara. Karya Aksara. Jakarta. 
Hakim, N. M., Y. Nyakpa, A. M. Lubis, S. G. Nugroho, M. H. Diha, G. B. Hong dan H. H. Bayley. 1986. Dasar-Dasar IImu Tanah. Universitas Lampung.

Hardjowigeno, S. 2003. IImu Tanah. Akademika Pressindo. Jakarta.

Harijati, Indrawati dan Dem Vi Sara. 1995. Pengaruh Kompos Berbahan Stimulator Berbeda terhadap Produksi Kangkung Darat (Ipomea reptans poir). Pusat Studi Indonesia, Lemlit Jakarta.
Roesmarkam, A dan N.W. Yuwono. 2002. IImu Kesuburan Tanah. Kanisius Yogyakarta.

Soepardi, G. 1980. Sifat dan Ciri Tanah. Fakultas Pertanian Institut Pertanian Bogor. Bogor.

Sutanto, R. 2002. Penerapan Pertanian Organik. Kanisius, Yogyakarta. 